\title{
Anatomy of the visceral cavity of Eugerres mexicanus (Teleostei: Gerreidae)
}

\author{
Abraham Kobelkowsky ${ }^{1 *} \&$ Jazmín Terán-Martínez ${ }^{2}$ \\ 1. Laboratorio de Peces. Departamento de Biología. Universidad Autónoma Metropolitana, Unidad Iztapalapa. Ciudad \\ de México, México; akobelkowsky@gmail.com \\ 2. El Colegio de la Frontera Sur. San Cristobal de las Casas, Chiapas, Ciudad de México, México; \\ jazminteran88@hotmail.com \\ * Correspondence
}

Received 08-V-2019. C Corrected 14-XI-2019. Accepted 22-II-2020.

\begin{abstract}
Introduction. The visceral cavity of teleostean fishes contains the kidneys, digestive tube and annexed glands, gas bladder, gonads, and spleen. Objective: To analyze and describe the anatomic relationships of the organs of the visceral cavity of the Mexican mojarra, Eugerres mexicanus. Methods: By means of dissections, we analyzed, described and illustrated the splanchnology of the visceral cavity of 10 adult specimens from the State of Chiapas, Mexico. Results: The visceral cavity is delimited by the precaudal vertebrae, the scapular and pelvic girdles, the pleural ribs, the first anal pterygiophore and several myotomes. Both kidneys, with extraperitoneal character are partially fused to each other, and contact the neurocranium, the precaudal vertebrae, and the gas bladder. The digestive tube does not present a stomach nor pyloric caeca, and it is 1.3 the standard length of the fish. The liver has two short right lobes. Both ovaries and testes are wide and reach the liver. The spleen is ovoid and is located on the left side of the duodenum. The gas bladder has two anterior lobes, its posterior end is in direct contact with the floor of the visceral cavity, and contain the urinary bladder. Discussion: The organization of the organs in the visceral cavity is in the anatomical pattern of the teleostean fishes, however, the organ that shows the highest number of special characters is the gas bladder, which as in other species of Eugerres is large and shows two notable anterior lobes, reinforced by epipleural ribs. Compared with other species of Eugerres, the Mexican mojarra shows, as exclusive characters: a) the union of the posterior end of the gas bladder with the floor of the visceral cavity, and, b) the location of the urinary bladder within the gas bladder.
\end{abstract}

Key words: splanchnology, mesonephros, gas bladder, digestive tract, gonads.

Kobelkowsky, A., \& Terán-Martínez, J. (2020). Anatomy of the visceral cavity of Eugerres mexicanus (Teleostei: Gerreidae). Revista de Biología Tropical, 68(1), 189-199.

Four genera of the so-called mojarras, Family Gerreidae occur in Mexico, namely: Eugerres (Jordan \& Evermann, 1927), Diapterus (Ranzani, 1842), Eucinostomus (Baird \& Girard, 1855), and Gerres (Quoy \& Gairmard, 1824). According to González-Acosta and Rodiles-Hernández (2013) the Eugerres genus is represented by three species in the Eastern Pacific: E. axillaris (Günther, 1864), E. brevimannus (Gúnther, 1864) and E. lineatus
(Humboldt, 1821), and by three in the Western Atlantic: E. awlae (Schultz, 1949), E. brasilianus (Cuvier, 1830) and E. plumieri (Cuvier, 1830).

The "Mexican mojarra", Eugerres mexicanus (Steindachner, 1863), called it as Diapterus mexicanus (Miller, Minckley, \& Norris, 2005) is a good representative of the ichthyofauna of the Usumacinta fluvial system. While GonzálezAcosta and Rodiles-Hernández (2013) reported 
Eugerres castroaguirrei as a new species, Martínez-Guevara et al. (2015), synonymized as E. mexicanus by means of morphological and molecular analyses. The Mexican mojarra is distributed in Southeastern Mexico and Northern Guatemala (Miller et al., 2005).

Anatomical studies of the Gerreidae family are relatively scarce, among them are those of: Green (1971), Andreata and Barbieri (1981), Cyrus and Blaber (1982), Kobelkowsky (2004), Parmentier, Mann and Mann (2011), Hernández et al. (2012), GonzálezAcosta, Rubio-Rodríguez and Ruiz-Campos (2014), and Terán-Martínez (2015).

The splanchnology (study of organs in vertebrates) implies anatomical knowledge of the coelomic cavities, which in fish are the pericardial and the visceral. While the pericardial cavity contains the heart, the visceral cavity includes the lung or its homologous, the gas bladder, the gonads, the spleen, and the digestive tube with its annexed glands. Additionally, this morphological discipline includes the study of the kidney, even though it is extra peritoneal. The anatomical knowledge of the organs of the teleosts provides the basis for the study of several biological aspects of the species, such as feeding, reproduction, osmoregulation, excretion and, in part, the gas exchange and buoyancy. In order to provide with anatomical information of structures that support aspects of the biology of E. mexicanus, here, we describe and illustrate the boundaries of the visceral cavity and the morphology of the organs contained in it.

\section{MATERIALS AND METHODS}

We used 10 male and female adult specimens of the Mexican mojarra E. mexicanus, collected in the state of Chiapas (ECO-SC-048, ECO-SC-398). The specimens were fixed in $10 \%$ formaldehyde and stored in $70 \%$ ethyl alcohol.

In order to topographically locate the organs within the visceral cavity, the coelomic cavity was exposed and described through the following dissection technique: the skin was removed from the left side of the body, between the opening of the operculum and the level of the anal and urogenital openings (Fig. 1). Next, the myotomes were removed from that side, until the pleural (ventral) ribs, the epipleural (dorsal) ribs, and the precaudal vertebrae were evident. The opercular and subopercular bones were removed and the branchial filaments were detached. The muscles associated with the scapular and pelvic girdles were removed. The infracarinalis medius muscle was left in place. The pleural and epipleural ribs were then disarticulated, with the exception of the first two epipleural ribs.

The postemporal bone was separated from the neurocranium, the Baudelot ligament was sectioned, and, both cleithra were separated by their symphysis, in order to remove the scapular girdle. Then, we determined the location of the organs within the visceral cavity and described their topographic relationships.

The mesonephric kidney was analyzed in situ, removing from its anterior portion the cranial and spinal nerves, to which contacts, as well as the anterior cardinal vein. The archinephric ducts were identified, which were sectioned in a point of their free trajectory. The ventral aspect of this organ was observed after the removal of the gas bladder.

The mature ovaries and testes were analyzed in situ from their lateral and ventral views, while their dorsal aspect was evident after sectioning the corresponding mesenteries that hang them from the gas bladder. After the gonads were separated from the visceral cavity, they were sectioned transversally to analyze their interior.

The gas bladder was examined in situ, describing its components, its anatomical relationships, and its relative volume. It was separated from its contact with the vertebrae and with the floor of the visceral cavity.

The digestive tube and its glands were observed in situ from their lateral view; they were then separated from the pharynx by sectioning the contact of the esophagus with the pharyngeal bones; likewise, they were separated from the floor of the visceral cavity by 


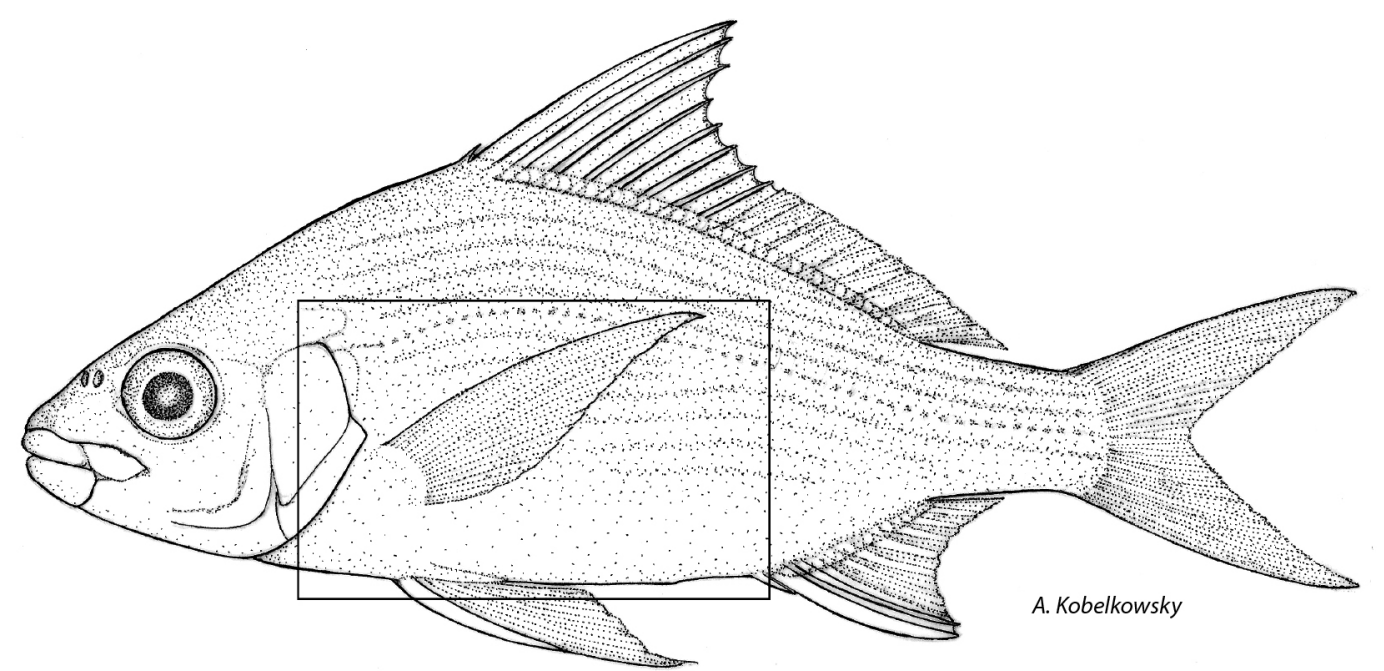

Fig. 1. Lateral view of the Mexican mojarra Eugerres mexicanus.

The squared area marks the boundary of the visceral cavity.

cutting around the anus. The location and shape of the spleen was described.

The illustrations were made using a drawing tube (camera lucida) attached to a Leica Wild M3Z stereomicroscope. The terminology for the endoskeleton followed the criteria of Gregory (1959) and Kobelkowsky (2004), and that of the musculature followed Winterbottom (1974) criterion.

\section{RESULTS}

Visceral cavity: The visceral cavity of $E$. mexicanus is oval shaped, both from its lateral aspect (Fig. 2A) and transverse section (Fig. $3)$; its length equals the cephalic length. It is delimited by the scapular and pelvic girdles and by the appendicular musculature, the precaudal vertebrae, the first pterygiophore of the anal fin, the infracarinalis medius muscles, the pleural ribs, and the hypaxialis muscles.

The largest volume of the visceral cavity is occupied by the gas bladder. The digestive tube, the liver, and the gonads (Fig. 2A, Fig. 2B, Fig. 3A, Fig. 3B) are within the lower portion of the cavity. The ovaries and testes are located between the digestive tube and the gas bladder (Fig. 2A, Fig. 2B, Fig. 3B).
The spleen is situated among some anterior intestinal loops (Fig. 3A, Fig. 6D). The kidney is placed, with an extraperitoneal character, dorsal to the gas bladder and ventral to the precaudal vertebrae (Fig. 2A, Fig. 2B, Fig. 3A, $3 \mathrm{~B}$ ), and it is extended towards the base of the neurocranium (Fig. 2A).

Urogenital system: Kidneys. The kidneys or mesonephros are elongated and fuse with each other from the level of the ninth vertebra to the back (Fig. 4B). The beginning of its left and right portions (Fig. 2A) is located at the level of the basioccipital and exoccipital bones, these portions are called anterior renal lobes (Fig. 2A, Fig. 2B, Fig. 4A, Fig. 4B). These lobes are connected with the lateral ends of the sinus venosus of the heart and each one is crossed by the Baudelot ligament (Fig. 2A, Fig. 4A), which holds the corresponding scapular girdle.

On the ventral surface of the kidney, and parallel to the right archinephric duct, the right posterior cardinal vein is observed (Fig. 4B), and reaches the anterior left renal lobe. On both edges of the posterior portion of the kidney, the archinephric ducts are observed (Fig. 4A, Fig. $4 \mathrm{~B})$, they fuse together at the posterior end of 


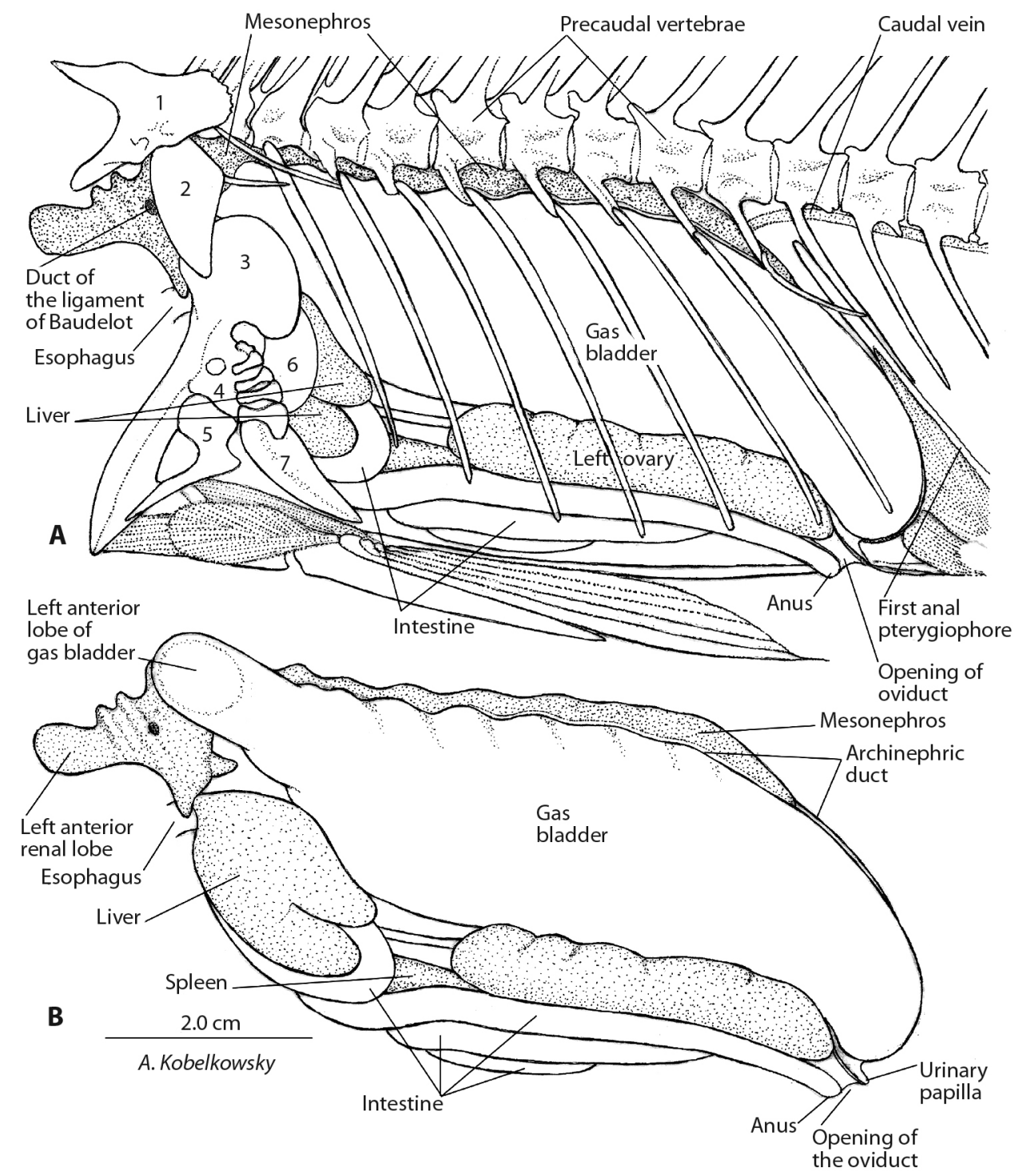

Fig. 2. Visceral cavity of Eugerres mexicanus. A. Left lateral view of the visceral cavity and its boundaries. B. Left lateral view of the organs of the visceral cavity.

the organ forming the common urinary duct. This duct descends attached to the first anal pterygiophore; however, it penetrates the back of the gas bladder where it connects to the urinary bladder. In this way, both the urinary bladder and the distal portion of the common urinary duct are located within the gas bladder (Fig. 5E). In males, the common sperm duct joins the common urinary duct forming the urogenital duct, whereas in females it remains independent.

Gonads. Both the ovaries and the testes are paired organs, which reach similar volumes when they mature. They are located ventrally to the gas bladder (Fig. 2A, Fig. 2B) from which they are suspended by lengthwise mesenteries 


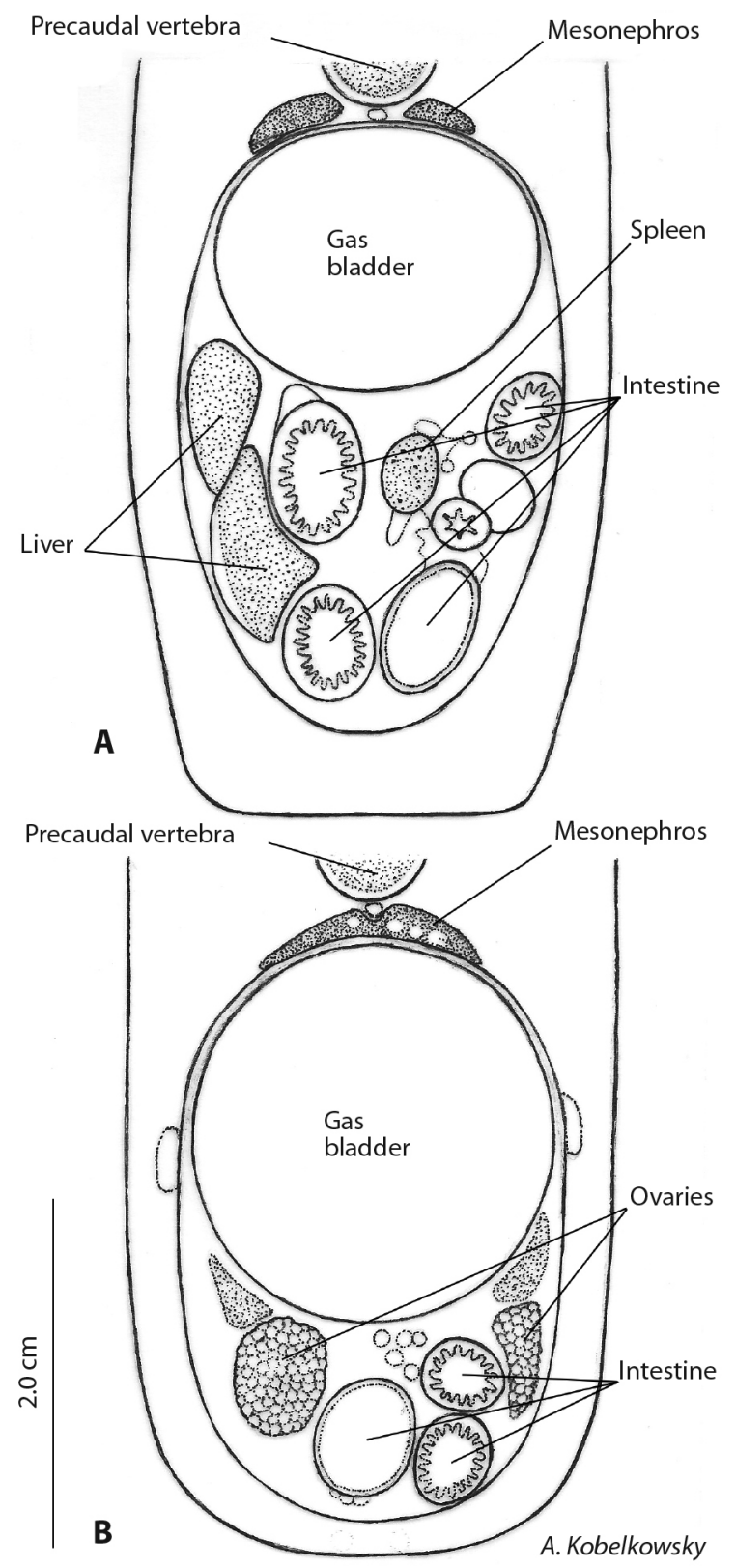

Fig. 3. Visceral cavity of Eugerres mexicanus. A. Transverse section at the level of the liver and spleen. B. Transverse section at the level of the ovaries.

(Fig. 4E, Fig. 4F). Both in the ovaries as in the testes, their left and right portions are in contact with each other (Fig. 4D).

The ovaries are elongated and their lateral edges are lobed (Fig. 2A, Fig. 2B, Fig. 4C, Fig. $4 \mathrm{D}$ ); from their dorsal surface the mesovarium emerges (Fig. 4E), and joins to the ventral surface of the gas bladder. Both ovaries are fused in its most posterior portion, where the unique oviduct is formed as a continuation of the ovarian tunic. The female genital opening is located anteriorly to the urinary orifice. In transverse 
Left anterior renal lobe

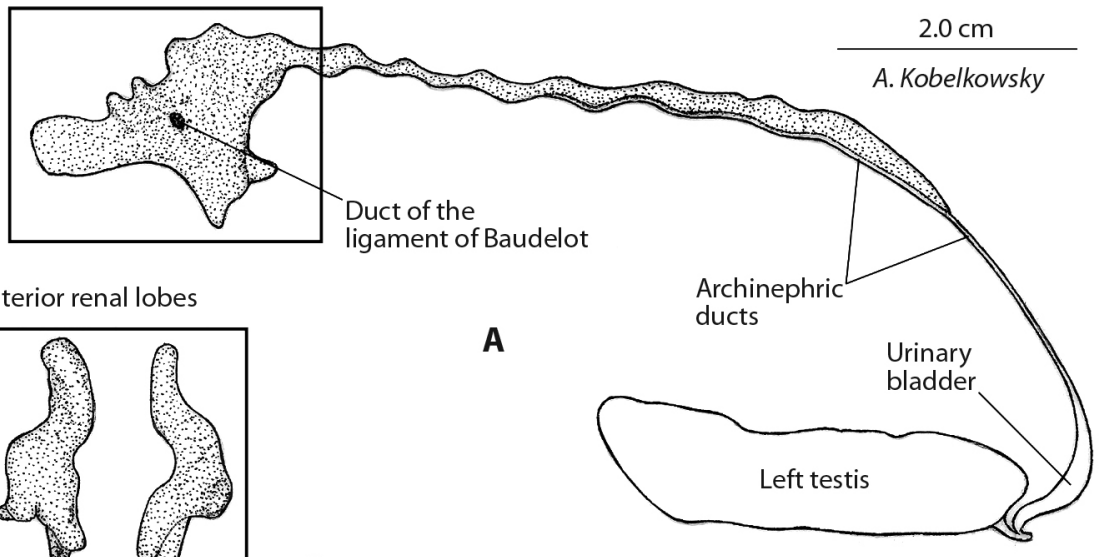

Anterior renal lobes

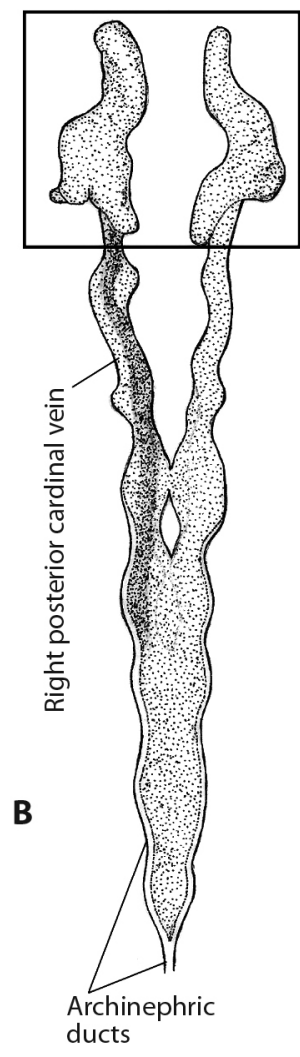

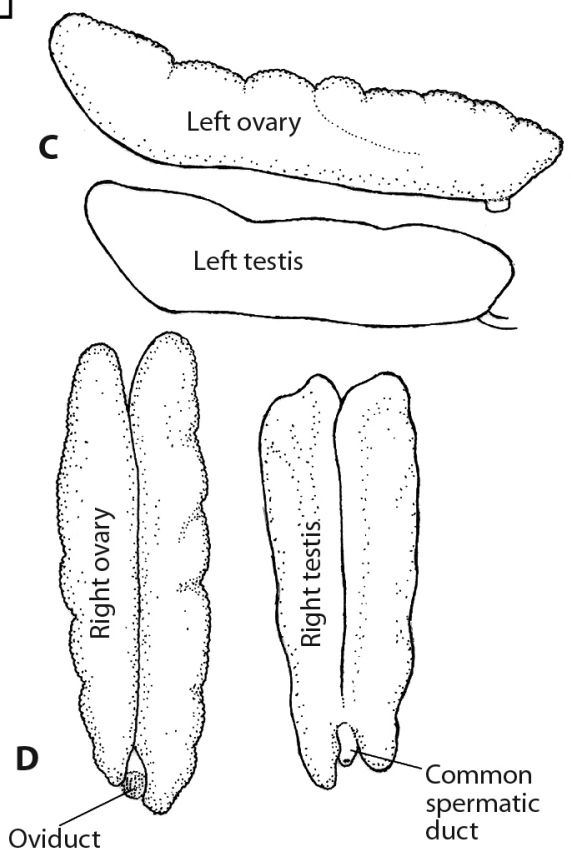

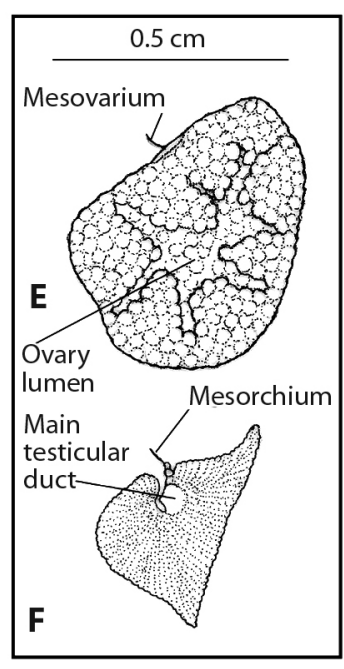

Fig. 4. Urogenital system of Eugerres mexicanus. A. Left lateral view of the mesonephros. B. Ventral view of the mesonephros. C. Left lateral view of the gonads. D. Dorsal view of the gonads. E. Transverse section of the left ovary. F. Transverse section of the left testicle.

section, the ovigerous lamellae are recognized starting from the entire internal surface and maintaining the lumen (Fig. 4E). The testes are elongated (Fig. 4C, Fig. 4D), with smooth edges, and from their dorsal surface the mesorchia, that attach to the ventral surface of the gas bladder, emerge. In transverse section, each testis presents a triangular shape, with numerous fine grooves, corresponding to groups of seminiferous lobules, which converge in the main testicular duct. Dorsal to this duct, the testicular vessels, and the mesorchium can be observed (Fig. 4F). Both main testicular ducts joined together to form the common spermatic 


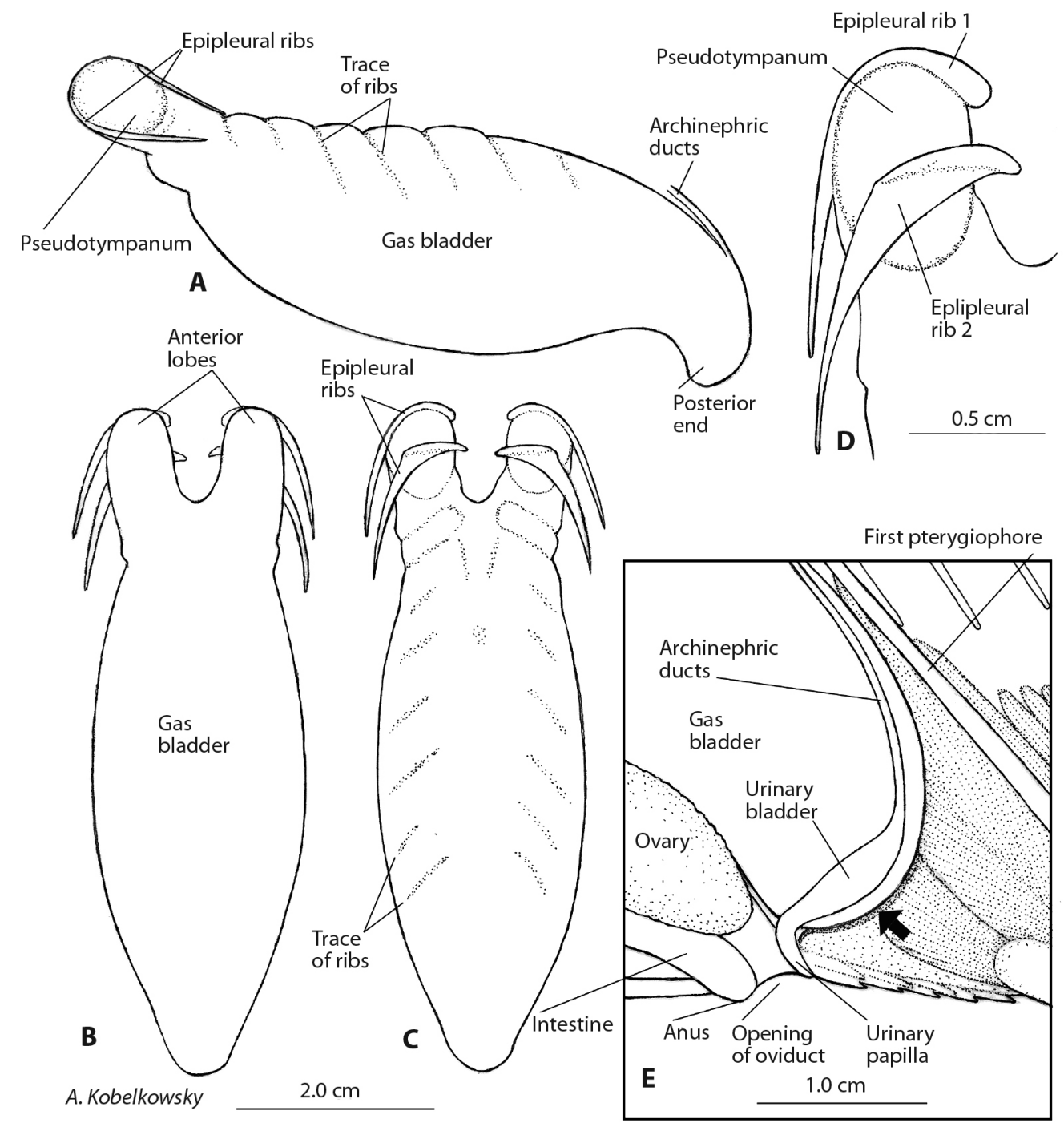

Fig. 5. Gas bladder of Eugerres mexicanus. A. Left lateral view. B. Ventral view. C. Dorsal view. D. Dorsal view of the left anterior lobe. E. Sagittal section of the posterior portion of the gas bladder. The arrow points to the floor of the visceral cavity.

duct, which in turn joins to the common urinary duct. The urogenital opening is located anterior to the anal fin.

Gas bladder: The gas bladder of $E$. mexicanus (Fig. 2A, Fig. 2B, Fig. 3A, Fig. 3B) is bulky, ovoid, elongated, with two anterior lobes (Fig. 5A, Fig. 5B, Fig. 5C) which form an anterior notch, and with the posterior end of tubular aspect which is fixed to the floor of the visceral cavity (Fig. 5E). It is anchored to the first vertebral centrum and to the pleural ribs (Fig. 2A). The anterior lobes are separated from each other by the retractores dorsalis muscles, which originate in the centrum of the first vertebrae and insert into the pharyngobranchial bones of the branchial arches. Each anterior lobe of the gas bladder is attached 
to the first two dorsal or epipleural ribs (Fig. 5D), in that way delimiting a small oval area of thinner walls named "pseudotympanum". Each pseudotympanum is close to the postemporal and supracleithrum bones. The posterior end of the gas bladder is directly fixed to the floor of the visceral cavity and it houses the urinary bladder and part of the archinephric ducts (Fig. 5E).

Digestive tube and liver: As a whole, the digestive tube of E. mexicanus shows an anterior portion in an oblique position and formed by several intestinal loops, and a posterior portion of longitudinal orientation formed by three intestinal loops (Fig. 6). The digestive tube is regionalized into esophagus and intestine, and lacks stomach and pyloric caeca.

The esophagus is narrow (Fig. 6B, Fig. 6D) and starts immediately behind the upper and lower pharyngeal bones, it passes between the anterior renal lobes and the two portions of the sinus venosus of the heart it is of medium length and curves down until it reaches the intestine. The stomach is not defined, in such way; the esophagus is directly connected with the intestine; at that point the entrance of the common bile duct is recognized. The most anterior portion of the intestine is the duodenum (Fig. 6B, Fig. 6D), which shows, in its beginning, a slight bulge. The intestine forms two forward facing loops and other two facing back; the first loop makes extensive contact

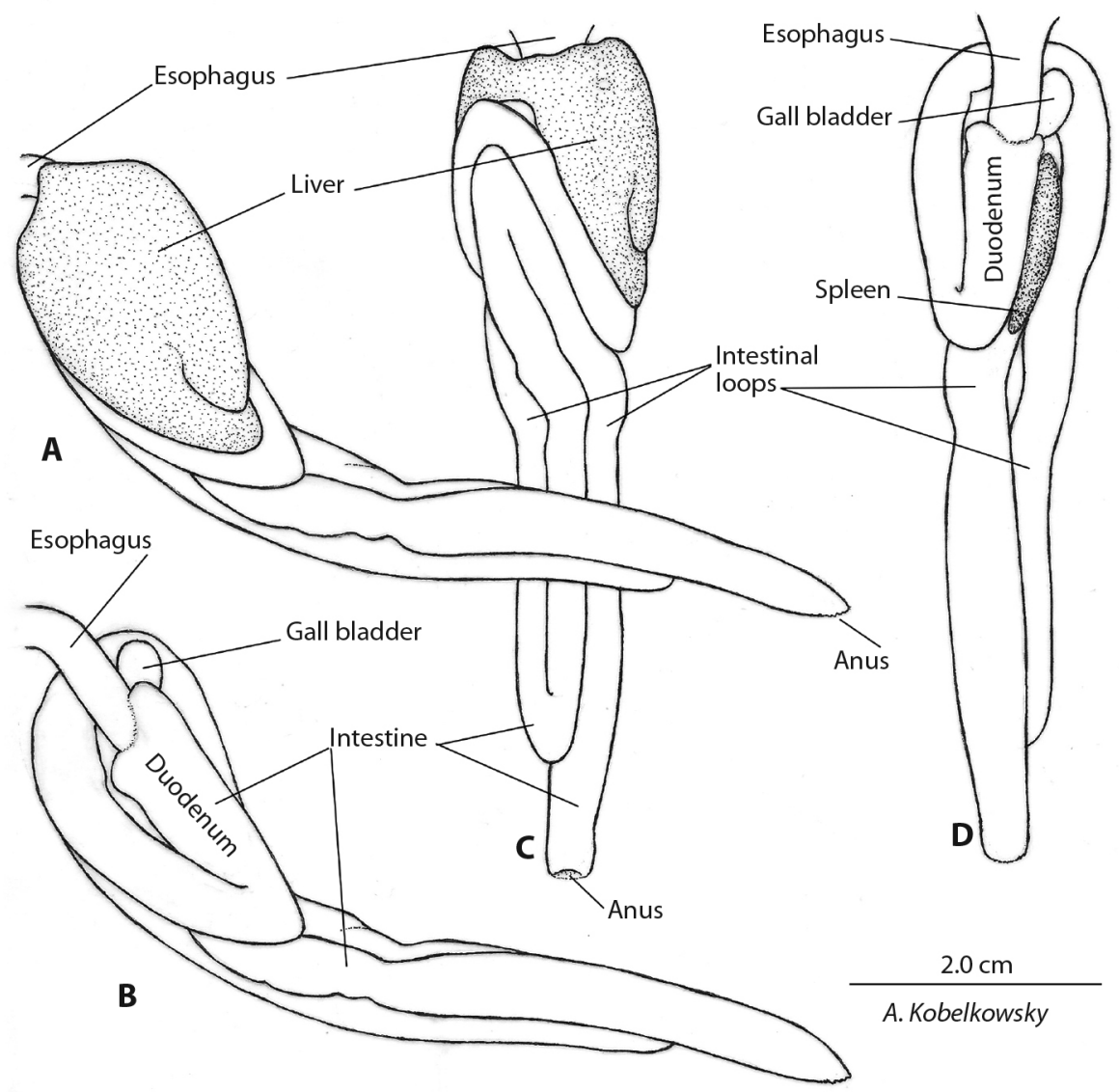

Fig. 6. Digestive tube and liver of E. mexicanus. a) Left lateral view. b) Left lateral view after removing the liver. c) Ventral view. d) Dorsal view after removing the liver. 
with the liver. From the second anterior loop, the intestine continues straight to the back to form the rectum, which opens to the outside through the anus (Fig. 2A), and it is anterior to the anal fin. The length of the intestine is about 1.3 of the standard length of the fish.

The liver is relatively small (Fig. 2B, Fig. 6A, Fig. 6C). It surrounds the esophagus ventrally, and its largest volume is located on the left side with two small lobes in its posterior end (Fig. 3A, Fig. 6A, Fig. 6C), whereas the right portion constitutes the right hepatic lobe. The gallbladder is oval-shaped and is located on the inner surface of the right hepatic lobe (Fig. 6B, Fig. 6D). The common bile duct is short and it is connected to the digestive tube at the junction of the esophagus with the intestine.

Spleen: The spleen is a dark red surface lanceolate organ located on the right side of the duodenum (Fig. 3A, Fig. 6D).

\section{DISCUSSION}

The morphology of the visceral cavity in the Mexican mojarra E. mexicanus, and the distribution of its organs, shows an organization that is within the general pattern of the Teleostei. The shape of the visceral cavity in the teleosts is related to the shape of the body. In that way, teleosts with a notable lateral flattening, such as the Clupeiformes and the Pleuronectiformes, show a compressed shape; those with a cylindrical body, such as the Anguilliformes, Beloniformes, and Syngnathidae, present a cylindrical cavity; and in those, whose bodies are dorso-ventrally flattened, like the Ogcocephalidae, this coelomic cavity is depressed.

The gross anatomy of the kidney of $E$. mexicanus is similar to that of other Perciformes, and in general the shape of the kidney in teleosts is determined by its contact with a considerable number of adjacent structures (Kobelkowsky, 2013), which is also observed in the present study. However, the special anatomical condition consisting in the entrance of the archinephric ducts to the gas bladder is to be noted, whereas in most teleosts the excretory system and the gas bladder are completely independent from each other.

Among the organs of the visceral cavity, the one that shows the highest number of special characters is the gas bladder. It develops the anterior lobes reinforced by the epipleural ribs and that carry the pseudotympana, it attaches its posterior end to the floor of the visceral cavity, and it includes the urinary bladder and part of the archinephric ducts in its interior.

The presence of the anterior lobes of the gas bladder of E. mexicanus, and its proximity with the postemporal and supracleithrum bones, is similar to that found in the genus Chaetodon (Chaetodontidae) (Webb, Smith, \& Ketten, 2006) and in Eucinostomus argenteus (Gerreidae) by (Parmentier et al., 2011). Possibly, this area of the anterior lobes corresponds to the structures that Parmentier et al. (2011) referred to as "pseudotympanum" in E. argenteus, and that probably participates in a hearing mechanism. However, the pseudotympana of $E$. argenteus are directly coupled to foramina of the otic capsules, whereas those of E. mexicanus are located close to the skin and to the postemporal and supracleithrum bones.

The role of the gas bladder in the transmission of sound is relatively frequent in teleosts, such as the Clupeidae (Whitehead \& Blaxter, 1989), the Sciaenidae (Sasaki, 1989), and mainly in the superorder Ostariophysi, in which the gas bladder is part of the Weber apparatus (Alexander, 1962), which transmits the sound to the otic capsules. Unlike E. mexicanus, the posterior end of the gas bladder of $E$. axilaris, E. lineatus, and E. plumieri does not reach the floor of the visceral cavity.

The most notable characters of the digestive tube of E. mexicanus are the absence of stomach and of pyloric caeca. According to Wilson and Castro (2010) the agastric character corresponds to around $20-27 \%$ of the teleostean fishes, and the absence of pyloric caeca is common in numerous groups of fishes. Stomachless condition is also reported in wrasses (Labridae) and parrotfishes (Scaridae) (Helfman, Collette, Facey, \& Bowen, 2009) and in silversides (Atherinopsidae) (Kobelkowsky \& Figueroa 
Lucero, 2018). The intestinal length/length ratio of E. mexicanus indicates an omnivorous feeding habit.

The outstanding aspect of the gonads of E. mexicanus is the remarkable volume of the mature testes, in contrast with many teleosts. The morphology of the ovaries of E. mexicanus is similar to that described Bairdiella chrysoura (Sciaenidae) (Kobelkowsky, 2012). While the spleen in E. mexicanus is located between two intestinal loops, in teleosts generally it has a diversity of locations, as it is functionally not related to other viscera.

Ethical statement: authors declare that they all agree with this publication and made significant contributions; that there is no conflict of interest of any kind; and that we followed all pertinent ethical and legal procedures and requirements. All financial sources are fully and clearly stated in the acknowledgements section. A signed document has been filed in the journal archives.

\section{ACKNOWLEDGMENTS}

The authors thank Tania KobelkowskyVidrio for the English translation of this article.

\section{RESUMEN}

Anatomía de la cavidad visceral de la mojarra mexicana Eugerres mexicanus (Teleostei: Gerreidae). Introducción: La cavidad visceral de los peces teleósteos contiene a los riñones, el tubo digestivo con sus glándulas anexas, la vejiga gaseosa, las gónadas y el bazo. Objetivo: Analizar y describir las relaciones topográficas de los órganos de la cavidad visceral de la "mojarra mexicana" Eugerres mexicanus. Metodología: Mediante disecciones se analizó y describió la esplacnología de la cavidad visceral de 10 ejemplares adultos recolectados en el estado de Chiapas, México. Resultados: La cavidad visceral, está delimitada por las vértebras precaudales, las cinturas, las costillas pleurales, el primer pterigióforo anal y varios miotomos. Los riñones, los cuales son extraperitoneales, están parcialmente fusionados entre sí. El sistema digestivo carece de estómago y ciegos pilóricos y su longitud corresponde a 1.3 de la longitud patrón. El hígado tiene dos lóbulos derechos. Las gónadas maduras son amplias. La vejiga gaseosa desarrolla dos lóbulos anteriores y su extremo posterior se une al piso de la cavidad visceral, e incluye a la vejiga urinaria.
Discusión: La organización de la cavidad visceral y sus órganos corresponde al patrón morfológico de los peces teleósteos, siendo la vejiga gaseosa el órgano que muestra el mayor número de caracteres especiales, como los lóbulos anteriores, la unión de su extremo inferior al piso de la cavidad visceral y la ubicación de la vejiga urinaria en su interior. Estos dos últimos caracteres la distinguen de otras especies del género Eugerres.

Palabras clave: esplacnología, mesonefros, vejiga gaseosa, tracto digestivo, gónadas.

\section{REFERENCES}

Alexander, R.M. (1962). The structure of the Weberian apparatus in the Cyprini. Proceedings of the Zoological Society of London, 139(3), 451-473.

Andreata, J.V., \& Barbiéri, L.R.R. (1981). Osteologia do crânio de Diapterus brasilianus (Cuvier, 1830) (Perciformes, Percoidei, Gerreidae). Revista Brasileira de Biologia, 41, 565-574.

Cyrus, D.P., \& Blaber, S.J.M. (1982). Mouthpart structure and function and the feeding mechanisms of Gerres (Teleostei). African Zoology, 17(3), 117-121.

González-Acosta, A.F., \& Rodiles-Hernández, R. (2013). New species of Eugerres from the Usumacinta Province, Mexico and Guatemala with a redescription of E. mexicanus (Steindachner, 1863) (Teleostei: Gerreidae). Neotropical Ichthyology, 11(2), 307-318.

González-Acosta, A.F., Rubio-Rodriguez, U., \& RuizCampos, G. (2014). El hueso urohial de los peces Gerreidae (Teleostei: Percoidei) de América y su aplicación taxonómica. International Journal of Morphology, 32(3), 923-929.

Green, J.M. (1971). Studies on the swim bladders of Eucinostomus gula and E. argenteus (Pisces: Gerridae). Bulletin of Marine Science, 21(2), 567-590.

Gregory, W.K. (1959). Fish Skull. A study of evolution of natural mechanisms. Florida, USA: Eric Lundberg.

Helfman, G.S., Collette, B.B., Facey, D.E., \& Bowen, B.W. (2009). The Diversity of Fishes. Biology, Evolution, and Ecology. Oxford, UK: Wiley Blackwell.

Hernández, R.E., Perera, M.A., Castillo, A., Luna, H., de la Cruz, J.A., Gómez, L.M., \& Valdez Zenil, J. (2012). Embryonic and larval development of Eugerres mexicanus (Perciformes: Gerreidae) in Tenosique: Tabasco, Mexico. Revista de Biología Tropical, 60(1), 369-379.

Kobelkowsky, A. (2004). Osteología de la mojarra de mar, Diapterus auratus Ranzani (Teleostei: Gerreidae). Hidrobiológica, 14(1), 1-10. 
Kobelkowsky, A. (2012). Morphological diversity of the ovaries of the mexican teleost fishes. International Journal of Morphology, 30(4), 1353-1362.

Kobelkowsky, A. (2013). Morphology and dissection technique of the kidney of the grey snapper Lutjanus griseus (Teleostei: Lutjanidae). International Journal of Morphology, 31(2), 553-561.

Kobelkowsky, A. \& Figuero Lucero, G. (2018). Anatomía del sistema digestivo del pescado blanco Chirostoma humboldtianum (Teleostei: Atherinopsidae). Hidrobiológica, 28(1), 37-50.

Martínez-Guevara, A., García-Rodríguez, F.J., CotaGómez, V.M., Hernández-Gómez, R.E., Perera-García, M.A., \& De La Cruz-Agüero, J. (2015). Eugerres castroaguirrei González-Acosta et Rodiles-Hernández, 2013 is a junior synonym of Eugerres mexicanus (Steindachner, 1863) (Actinopterygii: Perciformes: Gerreidae). Acta Ichthyologica et Piscatoria, 45(4), 393-401.

Miller, R.R., Minckley, W.L., \& Norris, S.M. (2005). Freshwater Fishes of Mexico. Chicago: The University of Chicago Press.

Parmentier, E., Mann, K., \& Mann, D. (2011). Hearing and morphological specializations of the mojarra (Eucinostomus argenteus). Journal of Experimental Biology, 214(16), 2697-2701.
Sasaki, K. (1989). Phylogeny of the family Sciaenidae, with notes on its zoogeography (Teleostei, Perciformes). Memoirs of the Faculty of Fisheries Hokkaido University, 36(1-2), 1-137.

Terán Martínez, J. (2015). Diversidad morfológica de la vejiga gaseosa en la familia Gerreidae (Pisces: Teleostei) (Master's thesis). Posgrado de Ciencias del Mar y Limnología, Universidad Nacional Autónoma de México, Mexico City, Mexico.

Webb, J.F., Smith, W.L., \& Ketten, D.R. (2006). The laterophysic connection and swim bladder of butterflyfishes in the genus Chaetodon (Perciformes: Chaetodontidae). Journal of Morphology, 267(11), 1338-1355.

Whitehead, P.J.P., \& Blaxter, J.H.S. (1989). Swimbladder form in clupeoid fishes. Zoological Journal of the Linnean Society, 97(4), 299-372.

Wilson, J.M., \& Castro, L.F.C. (2010). Morphological diversity of the gastrointestinal tract in fishes. In M. Grosell, A.P. farrell, \& C.J. Brauner (Eds.), Fish physiology (Vol. 30, pp. 1-55). London, UK: Academic Press.

Winterbottom, R. (1974). A descriptive synonymy of the striated muscles of the Teleostei. Proceedings of the Academy of Natural Sciences of Philadelphia, 125(12), 225-317. 